\title{
Amharic Text of Walda Madhen and English Translation
}


Stéphane Ancel, Magdalena Krzyżanowska, and Vincent Lemire - 9789004423862 Downloaded from Brill.com04/26/2023 01:08:31PM via free access 
The manuscript page numbers are displayed in the margin. The boundary between successive pages is marked within the text by a thin vertical stroke ( | ). In the English translation, the vertical strokes correspond approximately but not exactly to the strokes in the Amharic due to word order differences between the two languages. Corrections and additions made by the author are put in braces $(\{\ldots\})$; corrections and additions made by the editor/translator are put in square brackets $([\ldots])$. In footnotes, we indicate those orthographic and grammatical forms which deviate from the forms occurring in contemporary Amharic because they are obsolete, regional or simply erroneously written.

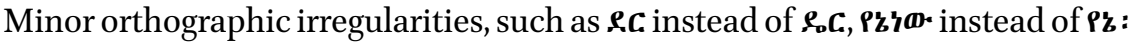
' $\boldsymbol{\omega} \cdot$, will not be signalled. 


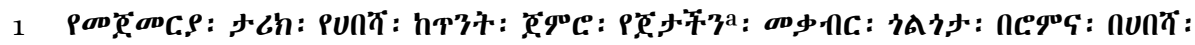

2 久.

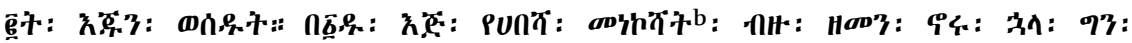

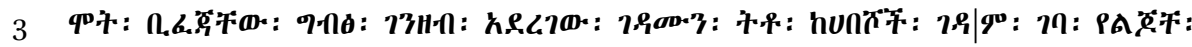

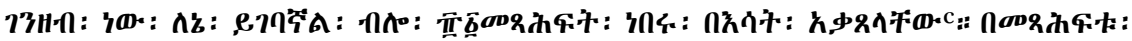

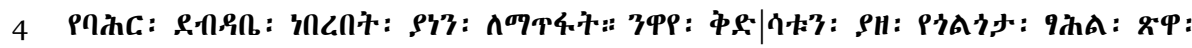

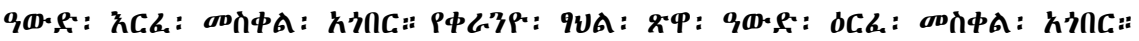

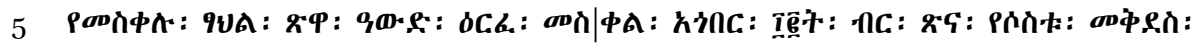

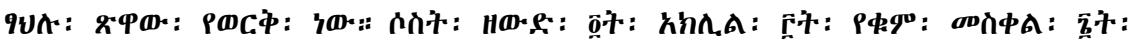

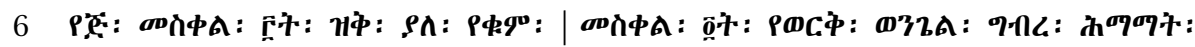

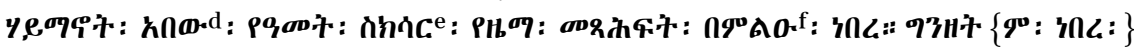

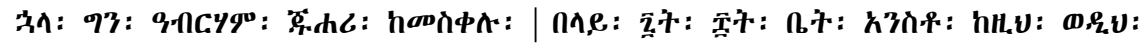

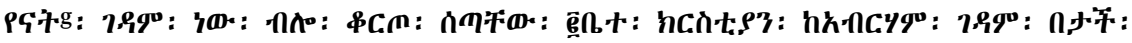

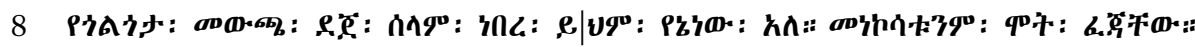

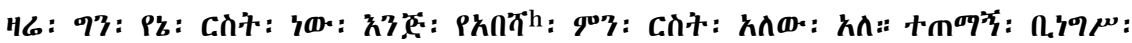

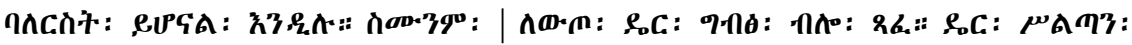

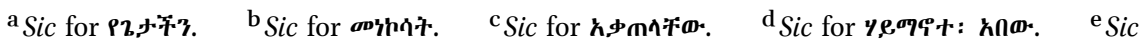

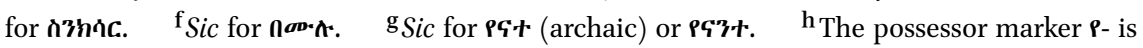
unnecessary.
}

1 This part of the text (p. 1 to 9) is based on another Amharic text written in ca. 1893. See Appendix $n^{\circ} 1$.

2 Throughout the text the author uses habashā when referring to Ethiopians. This term is an ancient ethnonym which refers to the people who live in the highlands of present-day Ethiopia, and which passed into English as 'Abyssinians', into Arabic as 'Habash', and into Ottoman Turkish as 'Habaş'. Smidt, W., and E. Ficquet. "Habäša." In Encyclopaedia Aethiopica, edited by A. Bausi. Vol. 5, 339-340. Wiesbaden: Harrassowitz Verlag, 2014. The Amharic term ityop'yāwi ('Ethiopian') does not occur.

3 Here the term 'Golgotha' is used to refer to the entire Holy Sepulchre complex. In the present text the term 'Golgotha' is also employed in reference to the sanctuary of Golgotha located inside the Holy Sepulchre basilica.

4 Here 'Rome' refers to Constantinople. The term is differently employed throughout the text: in reference to the city of Byzantium (and later Constantinople), to the Byzantine Empire as a whole, to the followers of the Eastern Orthodox Church as well as to the city of Rome in Italy.

5 The term faranj, derived from 'Frank', is used in Ethiopia to name the Westerners (with white skin). In this text, it refers to the faithful of the Roman Catholic Church (the Latins), the Europeans and the Crusaders.

6 Amh. gebts' 'Egypt'; the author applies this term in reference to the Egyptian Orthodox Christians.

7 All these items are used in the Ethiopian liturgy: ts'āhel is a flat round and ornamented dish (paten) with broad edges made of gold or silver used for keeping Eucharistic bread; $t$ 'ewwā is the chalice which receives wine; $\bar{a} w d$ is a large, flat plate (large paten) made of metal, copper 
The first history ${ }^{1}$ of the Ethiopians. ${ }^{2}$ Starting from ancient times, the tomb of our Lord, Golgotha, ${ }^{3}$ was in the hands of Rome ${ }^{4}$ and the Ethiopians. But when the Ethiopian king disappeared, the Armenians, the Faranj 5 [and] Rome, the three, | took two portions of the Ethiopian share. Ethiopian monks lived in the one [remaining] portion for a long time. But later when death finished them off, the Egyptians ${ }^{6}$ took possession of it. They left their [own] monastery and | entered the Ethiopian monastery. They said, "It is the property of our children. It should belong to us" [and] they burnt 81 books which were there. In the books there were archival records. [They burnt the books] to destroy them. They took sacred vessels: a paten, a chalice, a large paten, a spoon [and] an asterisk ${ }^{7}$ of [the sanctuary of] Golgotha; a paten, a chalice, a large paten, a spoon [and] an asterisk of the [sanctuary of] Calvary; a paten, a chalice, a large paten, | a spoon [and] an asterisk of the [sanctuary of the] Cross, [and] twelve silver censers; the patens and the chalices of the three sanctuaries were golden; three crowns, four diadems, three $\mid$ processional crosses, six hand crosses, three short processional crosses, four Golden Gospels, ${ }^{8}$ [the book for] the rite of the Holy Week, [the book entitled] Faith of the Fathers, the Synaxarion for the entire year [and] books with church music, all were there. There was also the [book of] the Funeral Ritual. But later Abraham Juhari | cut off [from the monastery] seven or eight houses [located] above the [sanctuary of the] Cross, ${ }^{9}$ [and] saying "From here on is your monastery", he gave them [the rest]. There were two chapels ${ }^{10}$ under the Abraham monastery, [on the way from Dayr al-Sultan to] the dajja salām, ${ }^{11}$ [meaning] the entrance ${ }^{12}$ of the Golgotha. "This | is also mine," he said. Death finished off the [Ethiopian] monks. "Now then [this] is my property, what is the Ethiopians' property?" he said. As [the proverb] says, "If the shareholder rules, he becomes the owner of the property". They [the Egyptians] changed the name [of the monastery] | and called it "monastery of

or bronze on which the ts'ähel-paten stands; erfa masqal is the spoon used for the distribution of the wine to the faithful; agobar is a small metal tripod (asterisk) standing on the large paten so that the veil would not touch the pieces of Eucharistic bread. Fritsch, E. “Qəddase: Paraphernalia." In Encyclopaedia Aethiopica, edited by S. Uhlig. Vol. 4, 275-278. Wiesbaden: Harrassowitz Verlag, 2010, 276-277.

8 'Golden Gospel' is the main Four Gospels book (containing Gospels of Matthew, Mark, Luke and John) possessed by a church which often contains miniatures and copies of documents. Sometimes it has more or less richly decorated cover.

That means the Dayr al-Sultan monastery which is situated above the chapels dedicated to Saint Helena and to the Finding of the Cross.

10 The present-day Chapels of Saint Michael and of the Four Living Creatures.

11 The term dajja saläm refers to a building at the entrance of the compound encircling an Ethiopian church.

Lit. 'the exit'. 


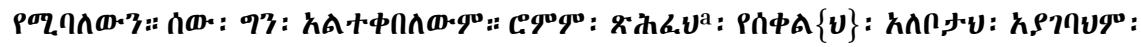

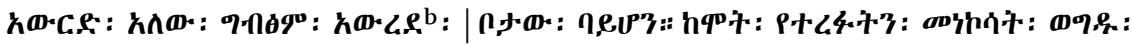

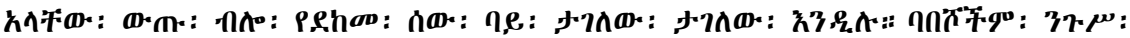

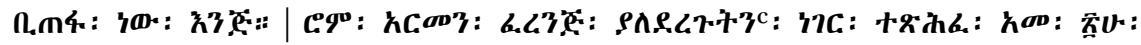

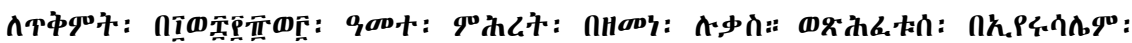

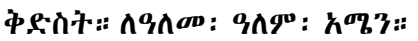

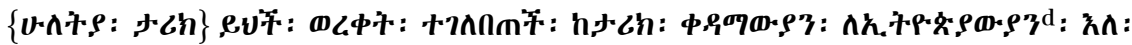

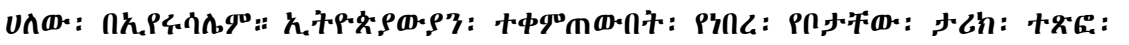

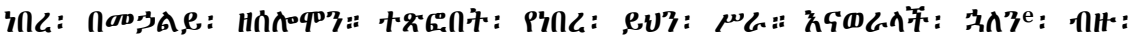

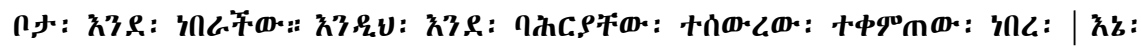
久

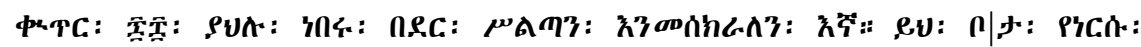

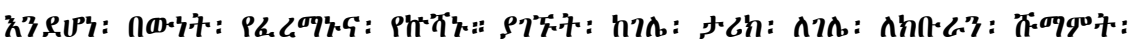

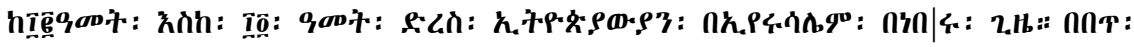

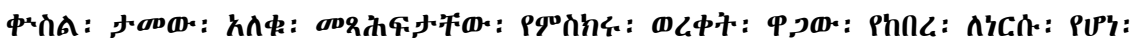

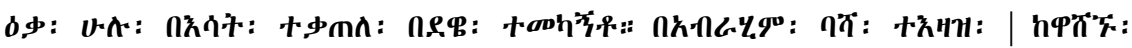

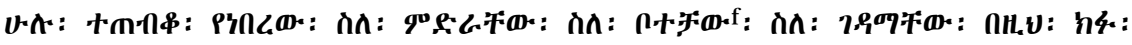

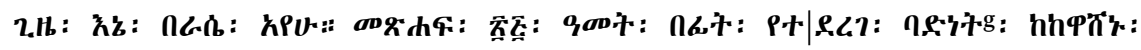

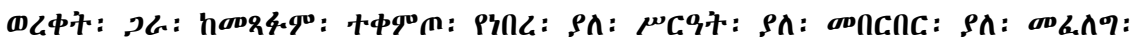

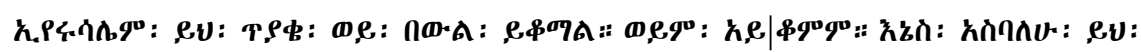

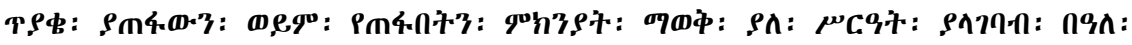

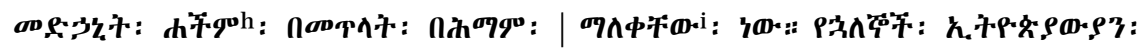

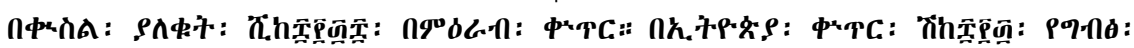

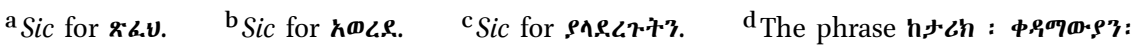

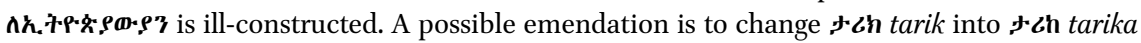

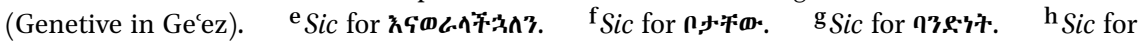

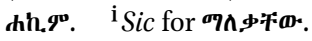

13 Here 'Rome' refers to the Orthodox Greeks.

14 The full proverb reads: "When I see a weak man, I want to fight him but I keep quiet when there is someone stronger than me."

15 Unclear sentence. It is difficult to understand to what "this thing" refers.

16 October $30,1890 \mathrm{AD}$.

17 The sentence is written in Ge'ez. The following lines (from p. 12 to 33) are a "free" translation of a letter written by Samuel Gobat in $185^{2}$. See Appendix $n^{\circ} 2$.

18 In Ge'ez mahāley zaSalomon; such a text indeed exists but appears to be very rare. The author may simply mean the Song of Songs (ascribed to King Solomon) contained in each Ethiopian Psalter.

19 This is a totally enigmatic sentence.

20 Samuel Gobat speaking here, as in the following lines until p. 33.
} 
Egypt", and wrote it [on a sign], whereas it was called Dayr al-Sultan. But no one accepted it. Rome ${ }^{13}$ said [to the Egyptians], "You are not allowed to hang the sign in a place that does not belong to you". And so the Egyptians took [it] down | because it was not their place. [But] they said to the monks who had escaped death "Go away!" They said "Go out!" As [the proverb] says, "When I see a weak man, I want to fight with him". ${ }^{14}$ It [happened] because the king of the Ethiopians disappeared. | Rome, the Armenians [and] the Faranj did not do this thing. ${ }^{15}$ [This] was written down on 2oth T'eqemt 1883 year of mercy in the era of [Saint] Luke. ${ }^{16}$ And the writing [took place] in the Holy Jerusalem. For ever and ever, Amen.

\{The second history\} This letter was copied from a history of the previous Ethiopians who were in Jerusalem. ${ }^{17}$ The history of the place where the Ethiopians were living [in Jerusalem] was written $\mid$ in the Songs of Solomon. ${ }^{18}$ We will tell you the history which was written about it, that they [the Ethiopians] had many places. Just like their character they remained hidden. ${ }^{19} \mid$ I know $^{20}$ that all their places were lost [and] that only one, Dayr al-Sultan, remained. We testify that the number of monks that were in Dayr al-Sultan equalled 68.|This is truly their place, by firmans ${ }^{21}$ and documents that we found in anyone's story to any honoured official. ${ }^{22} 12$ to 14 years [ago], when the Ethiopians were in Jerusalem, | they suffered from abscesses ${ }^{23}$ and perished. Their books, certificates, all things that were precious for them were burnt on the pretext of the disease, on the orders of Ibrahim Pasha. ${ }^{24} \mid$ In those bad times, all documents preserved [by the Ethiopians] about their land, about their places, about their monasteries, [were burnt]. I myself saw the books stored together with the documents 25 years ago. ${ }^{25}$ | What was together with the books [burnt in] Jerusalem without rule, without research, without investigation? This question will be answered or it will continue to be raised. ${ }^{26} \mid$ As for me, I think, the question [is] to know who destroyed [the library] or what the reason [was] for destroying it [in such an] improper [way], out of order. Because [the Ethiopian monks] hated doctors, they perished by disease $\mid$. The last Ethiopians died of wounds [in] 1838 in the Western calendar, [in] 1830 in the Ethiopian calendar. The

\footnotetext{
21 A firman is a decree of the Ottoman Empire authorities.

22 The Amharic sentence is ill-constructed and hard to understand.

23 Lit. 'swollen wounds', meaning the abscesses caused by the epidemic disease (plague).

24 Ibrahim Pasha (1789-1848) was the governor of Palestine from 1833 to 1841 on behalf of his father, the khedive of Egypt Muhammad 'Ali (176o-1849).

25 Samuel Gobat went to Jerusalem in 1826.

26 This sentence, like the previous one, is unclear and so its translation is only provisional.
} 


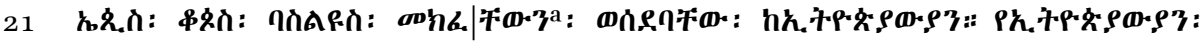

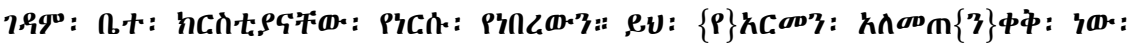

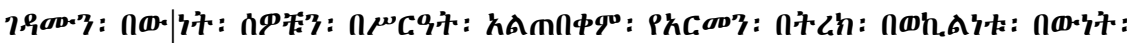

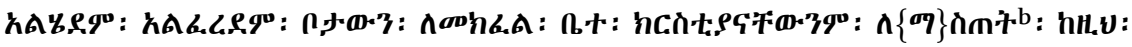

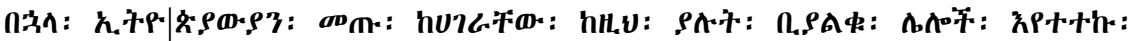

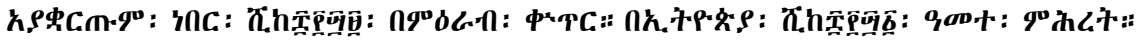

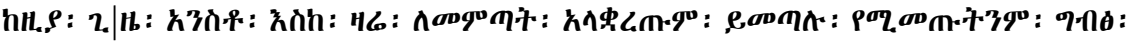
久C.03: k3

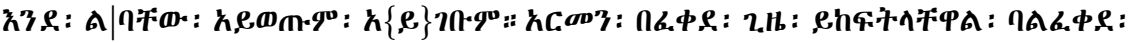

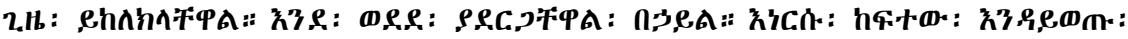

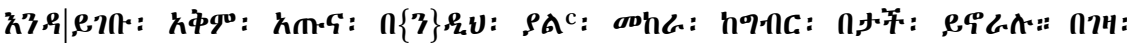

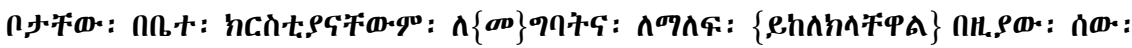

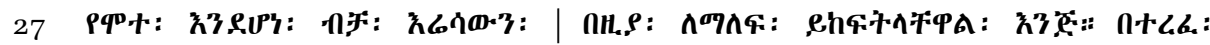

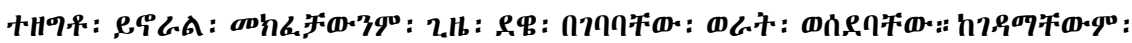

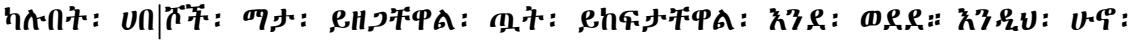

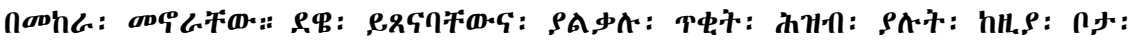

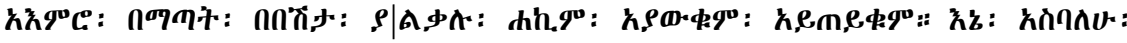

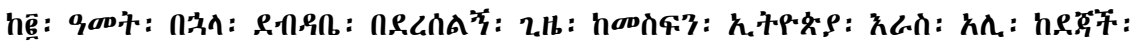

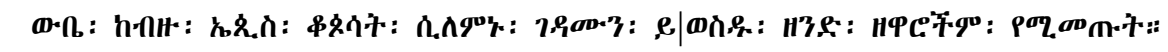

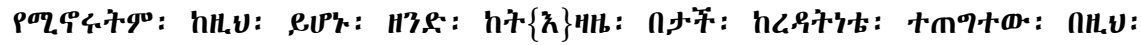

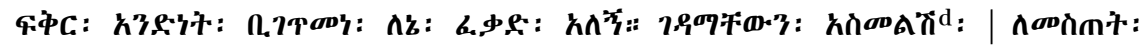

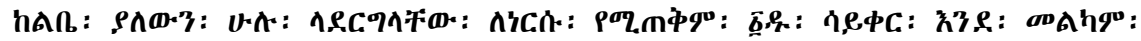

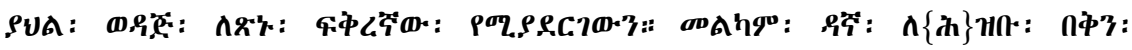

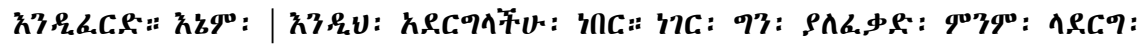
久А ЕА

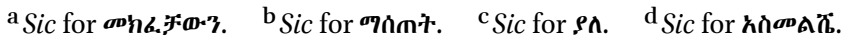

27 Basiliyus was the Coptic bishop of Jerusalem from 1856 to 1899 . Thus, despite what the author (but not Gobat) says, Basiliyus could not be present at that time in Jerusalem.

28 Armenians were supposed to 'represent' Ethiopians to the authorities of Jerusalem.

29 The author's mistake: years in Western calendar do not correspond to 'year of mercy' but 'anno domini' (A.D.).

30 It is unclear in this text whether they were the Armenians or the Egyptians who took the key. In Gobat's letter, they were clearly the Copts (Egyptians).

31 Going from the Ethiopian monastery to the Holy Sepulchre one passes through the chapels of the Four Living Creatures and of Saint Michael.

32 Ali II (also known as Ali Alula) ruled over central Ethiopia between 1830 and 1853 . Amharic rās is the third highest rank after negus (king), and negusa nagast (king of kings) in the hierarchy of Ethiopia at that time. 
Egyptian bishop Basiliyus ${ }^{27}$ | took from the Ethiopians their key, the Ethiopian monastery [and] the chapel that belonged to them. This [happened] because of the carelessness of the Armenians. They did not truly protect the monastery | [and] did not appropriately protect the people. The Armenian Patriarch did not truly act as a representative. ${ }^{28} \mathrm{He}$ did not arbitrate the issue of how to share the place, nor the return [to the Ethiopians] of the chapel. After that | the Ethiopians came from their country, in 1849 year of mercy in the Western calendar, ${ }^{29}$ in 1841 year of mercy in the Ethiopian [calendar]. When those who were here perished, others did not stop replacing them. From that time $\mid$ until today they have not stopped arriving; they are coming. And those who come, the Egyptians [and] the Armenians humiliate and treat them as slaves, as animals. They can neither go out freely | from their own chapel nor enter [it]. The Armenians open it for them when they [the Armenians] want to [and] they prohibit them when they do not want. [The Armenians] treat them as they wish, violently. [The Ethiopians] have lost the capacity to open [the monastery] in order to go out and to $\mid$ enter, and so they live in this kind of anguish in servitude. They [the Armenians/Egyptians ${ }^{30}$ ] forbid them to enter and to pass through their own chapel. ${ }^{31}$ Only if someone has died they open for them so that the corpse | can pass through it. But [apart from that] it [the chapel] is kept closed. [The Armenians/Egyptians] took away the key in the months when the disease struck them [the Ethiopians]. They shut in | the Ethiopians who are in their monastery in the evening and let them out in the morning, as they wish. In this way, living in misery they [the Ethiopians] are plagued by diseases and perish. The few people that are there are dying because of losing their mind [and] because of illness.|They do not know doctors, they do not ask [for them]. Me, I think, two years after that, a letter reached me from the Ethiopian lords, from rās Ali, ${ }^{32}$ from dajjāch Wubē ${ }^{33}$ [and] from many ecclesiastics, in which they begged [me] to take | [responsibility for] the monastery, the pilgrims who are coming and those who live here, [so that they will] be under my authority [and] have my assistance. If we are bound by this kind of love, I have a wish: to make give their monastery back |; to do everything from my heart that is useful for them, without exception, like a good lover does for his steady beloved [and] like a good judge who fairly judges his people. Me, | I would act for you like this. However, I cannot do anything without permission. For permission has not come to me; but I thought, if only permission would come from the

33 Wubē (Webē Hayla Māryām) ruled over northern Ethiopia (Tigray) between 1835 and 1855 . Amharic dajjāzmāch (abbreviated here to dajjāch) is a high military rank in the Ethiopian army, usually just below the rank rās. 


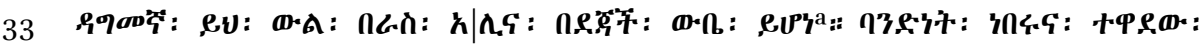

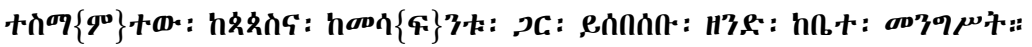

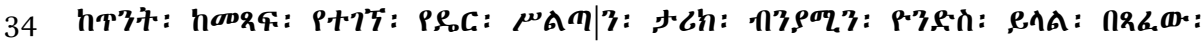

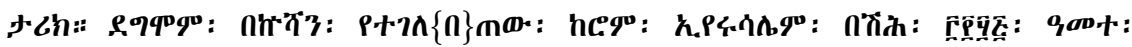

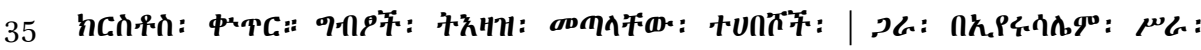

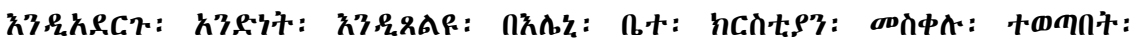

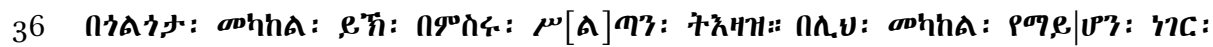

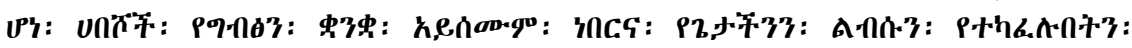

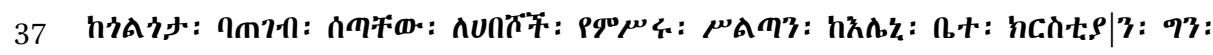

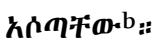

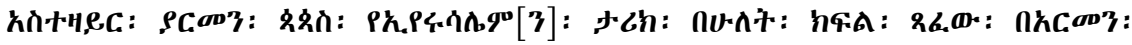

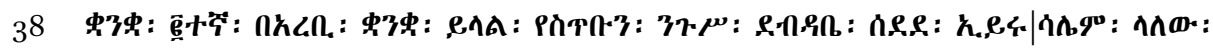
s,

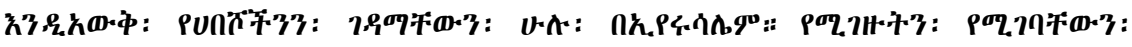
中.,

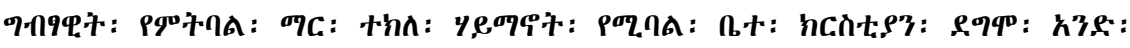

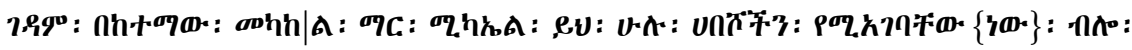
26.:

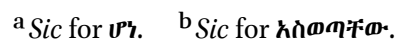

34 The text beginning from this sentence until page 47 is a translation of another text contained in an Italian document written by a certain Giovanni Battista Albengo in 1893 . See Appendix $\mathrm{n}^{\mathrm{o}} 3$.

35 Amh. benyāmin yondes.

36 Here 'Rome' refers to Constantinople.

37 Here 'Golgotha' refers to the Holy Sepulchre complex. 
English queen. Secondly, this agreement was concluded by rās Ali | and by dajjāch Wubē. They united together and, loving each other, they agreed to hold an assembly with the bishop and the princes in the palace [of the Ethiopian government].

A history of Dayr al-Sultan found in an ancient book. ${ }^{34}$ | Benjamin Ioannidès, ${ }^{35}$ in the history which he wrote, says [what follows]. Also, [this history] was copied in the documents [produced] by Rome ${ }^{36}$ [in] Jerusalem. In 1355 year of Christ an order came to the Egyptians to work together with the Ethiopians | in Jerusalem [and] to pray together in the Chapel of [Saint] Helena where the Cross appeared in the centre of Golgotha. ${ }^{37}$ This [happened] on order of the sultan of Egypt. [But] something happened between [the Ethiopians and the Egyptians] | that should not have happened. As the Ethiopians did not understand the language of the Egyptians, the sultan of Egypt gave to the Ethiopians [a place] near the Golgotha where our Lord's clothes were divided. ${ }^{38}$ But he removed them from | the Chapel of [Saint] Helena.

Astvatzatour, ${ }^{39}$ the Armenian metropolitan wrote the history of Jerusalem in two parts-[the first] in the Armenian language [and] the second in the Arabic language - [and he] says: "The king of Istanbul sent a letter to the qadi ${ }^{40}$ | of Jerusalem in 1005 according to the Islamic calendar, in 1607 according to the Christian calendar, ${ }^{41}$ to know all the monasteries of the Ethiopians in Jerusalem which they administer and which they are entitled to. |The qadi answered thus: [the monastery] called Mar Abraham, also Holy Saviour [chapel], [the chapel] which is called Mary the Egyptian, the chapel which is called Mar Takla Haymānot, also one monastery in the middle of the town | [called] Mar Michael. This is all that relates to the Ethiopians", $\mathrm{e}^{42}$ wrote.

38 The Chapel of the Sharing of the Raiment. Here 'Golgotha' means the sanctuary of Golgotha, inside the basilica of the Holy Sepulchre.

39 Amh. astazāyer. Astvatzatour (Astadzadour in the original document) was the Armenian patriarch in Jerusalem in 1645-1666 and 1670-1672. Basmadjian, K.J. "Chronologie de l'histoire de l'Arménie." Revue de l'Orient Chrétien 9, (1914): 369-371. In Muslim countries, the qadi is a judge and attorney in charge of civilian, judiciary and religious cases.

41 The dates do not correspond. In the original document, the dates are different: 1015 of Hegira for $1606 \mathrm{AD}$.

The author may be referring to the qadi of Jerusalem or (more probably) to Astvatzatour. 


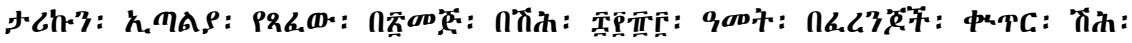

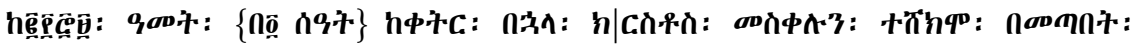

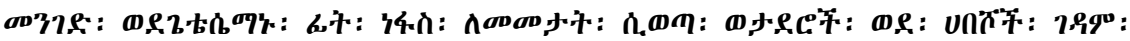

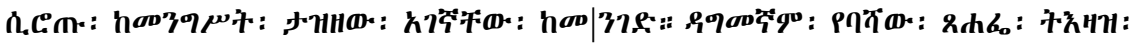

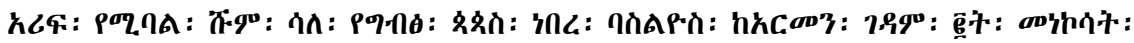

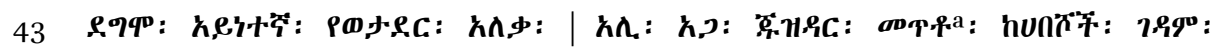

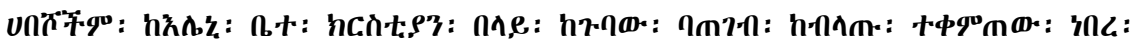

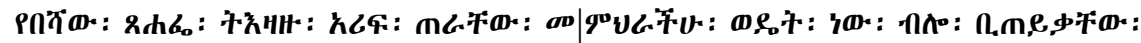

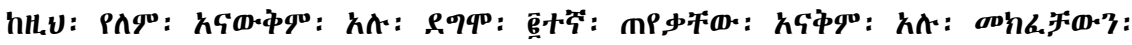

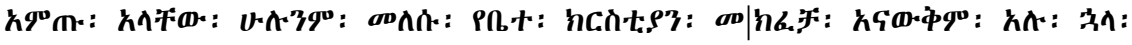

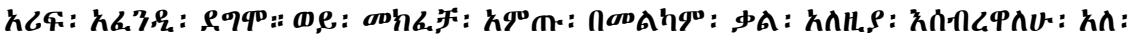

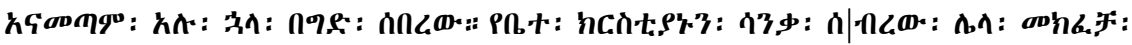

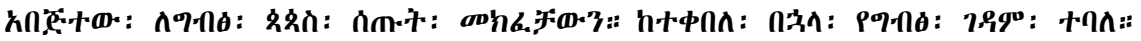

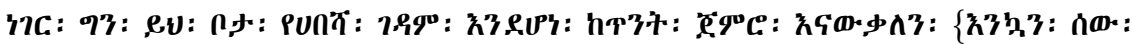

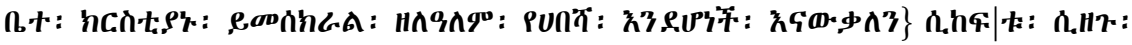

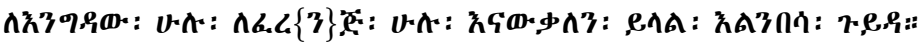

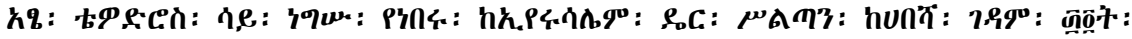

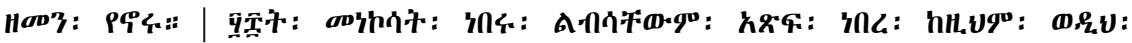

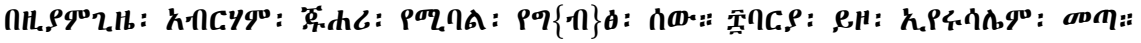

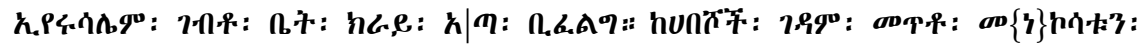

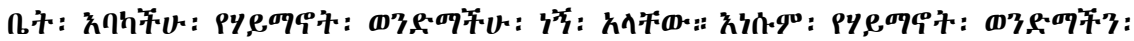

\footnotetext{
a Sic for apr+a.
}

43 Amh. māj. This is the transcription in Ethiopian characters of the Italian month 'maggio' (May).

44 Here again the dates do not correspond because of a mistake made while copying. In the original document it is May 20, 1863 AD (and not 1883) which, in fact, corresponds to 1279 of Hegira.

45 i.e. the Via Dolorosa.

46 The garden of Gethsemane is the place where, according to the Gospels, Jesus prayed for the last time before his crucifixion. It is now located at the foot of the Mount of Olives, west of the Old City of Jerusalem.

47 This refers to a place next to the cupola of Saint Helena's Chapel ("the raised place"), in the middle of the terrace of Dayr al-Sultan.

48 Amh. afandi. 'Effendi' is a Turkish title given to civil officers in the Ottoman Empire.

49 The author did not understand the signature of the original document ' $G$. Btta. Albengo, guida dei viaggiatori in Palestina' (Giovanni Battista Albengo, guide for travellers in Palestine). He transcribed it wrongly into elenbasā guydā: probably, 'elen-' corresponds to 'Albengo', '-basā' to the Turkish title 'pasha', and 'guydā' to 'guida'. 
An Italian wrote this story on $20 \mathrm{May}^{43}$ in the year 1883 according to the calendar of the Faranj, in the year 1279 [after Hegira]. ${ }^{44}$ \{At 4 o'clock\} in the afternoon, on the way on which $\mid$ Christ carried the cross, ${ }^{45}$ in the direction of Gethsemane, ${ }^{46}$ when he [the Italian] went out to get some fresh air, on the way he encountered some soldiers running to the monastery of the Ethiopians on the orders of the [local] authorities |. Furthermore, the pasha's secretary, an official called 'Arif, assisted by the Egyptian metropolitan Basiliyus, by two monks from the Armenian monastery and by the main military commander | Ali Agā Juzdār, came to the Ethiopian monastery. The Ethiopians were sitting above the Chapel of [Saint] Helena, on the raised place, on the covering of the roof. ${ }^{47}$ 'Arif, pasha's secretary, called to them, | "Where is your superior?" [The Ethiopians] answered, "He is not here, we don't know". Again, he asked them for the second time [and] they said, "We don't know". He said to them, "Bring the key!" All answered, "We don't know [anything about] the key $\mid$ of the chapel". So then 'Arif Effendi ${ }^{48}$ said, "Either you will bring the key willingly or I will break it [the door] down". "We will not bring [it]", [the Ethiopians] said. Then, ['Arif] broke it [the door] down by force. He broke | the door of the chapel, made another key and gave it to the Egyptian bishop. After he received it, [the monastery] was called the Egyptian monastery. But we know that from ancient times this place was an Ethiopian monastery. \{Not only the people, but [also] the church [itself] bears witness. We know that [it] is Ethiopian forever.\} Elenbasa auyd $\bar{a}^{49}$ says, "We know that [the Ethiopians] open | and close [the doors of the monastery] for all visitors, for all Faranj."

Before King Tewodros came to power [in Ethiopia], 34 years [earlier], there were 58 monks who lived in Jerusalem, in Dayr al-Sultan, the Ethiopian monastery. ${ }^{50}$ Their clothes were ats'ef. ${ }^{51}$ After that, at that time an Egyptian called Abraham Juhari came to Jerusalem bringing eight slaves. He entered Jerusalem and however much he looked he could not find a house to rent.| He came to the monastery of the Ethiopians and he said to the monks, "[Give me] a house, I beg you. I am your brother in faith". [The Ethiopian monks] said, "He is our brother

$5^{\circ} \quad$ This chapter was composed by the author of the text. He starts with an ill-constructed sentence by which he wants to give an idea about the period he describes. King of Kings Tewodros came to power in 1855 , so the facts he describes occurred, according to him, in 1821. See Chapter 5, pp. 139-140.

$5^{1}$ A type of garment worn by Ethiopian monks which is made of the tanned hide of an ox or an antelope. 


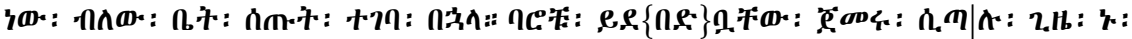

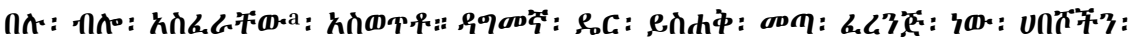

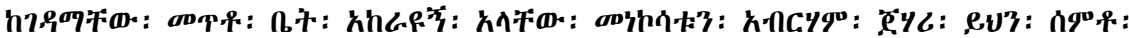

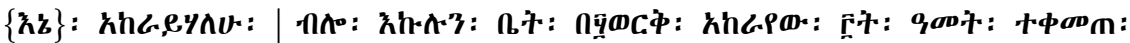

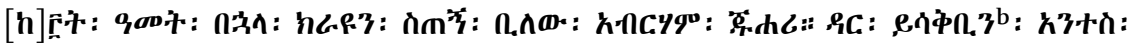

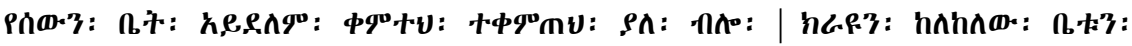
久.

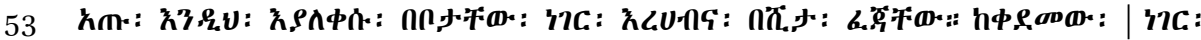

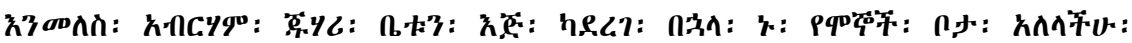

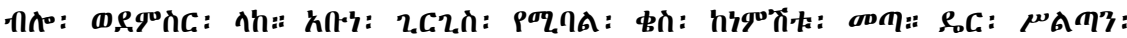

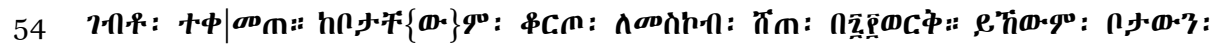

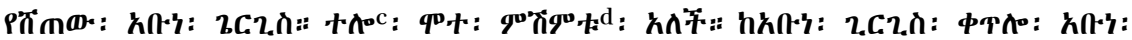

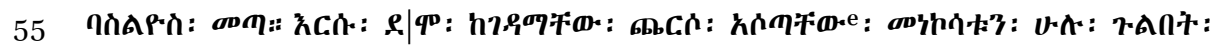

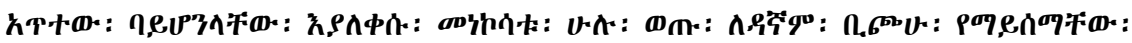

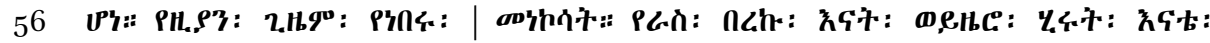

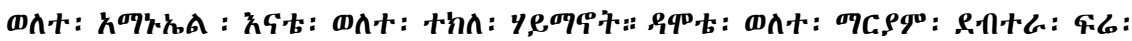

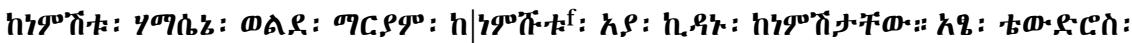

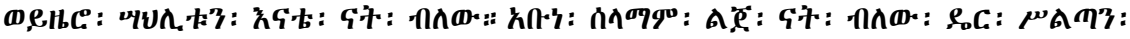

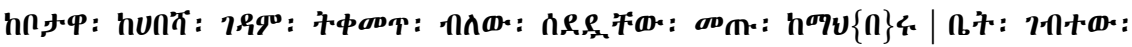

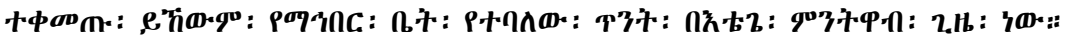

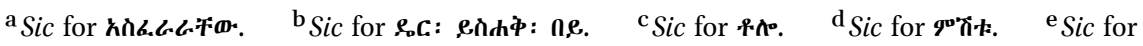

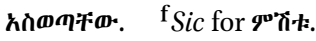

52 The author adds the term 'bey' to Dēr Yeshāq. The Turkish title bey was only an honorific title at that time, but it indicated a high social position.

53 Amh. sarāy. The Saray was the headquarters of the urban authorities in the Ottoman Empire.

54 Lit. 'this place thing'.

55 The Ge'ez word abuna (lit. 'our father') is used in Ethiopia for addressing high-ranking eccelesiastics. Nosnitsin, D. "Abunä.” In Encyclopaedia Aethiopica, edited by S. Uhlig. Vol. 1, 56. Wiesbaden: Harrassowitz Verlag, 2003.

56 The Amharic term wayzaro is nowadays used in a similar way as the English 'Mrs', but at that time it was used only for women of noble descent.

57 Dāmot is a region in the central-western part of Ethiopia.

$5^{8} \quad$ Dabtarā is an ecclesiastic title for cantors and learned unordained clerks.
} 
in faith" and [they] gave him a house. After he entered [the monastery], his slaves started to beat [the Ethiopians]. | While they were fighting, he said [to the Ethiopians], "Come here", [then] he intimidated them [and] made them leave. Then, Dēr Yeshaq came. He was a Faranj. He came to the monastery and said to the Ethiopian monks, "Rent me a house". Abraham Juhari heard this [and] said, " $\{\mathrm{Me}\}$ I will rent [it] to you" | and rented him half of the house for $5^{\circ}$ [coins of] gold. [Dēr Yeshaq] stayed [there] for 3 years. After 3 years, when Abraham Juhari said to Dēr Yeshaq52 "Give me the rent", [Dēr Yeshaq] said, "Didn't you take over someone's house and settle there?" | He refused him the rent, and took over the house. The Ethiopians and the monks went to the Saray, ${ }^{53}$ to the judge. When they complained, there was no one to listen to them. Weeping like this because of this occupancy problem, ${ }^{54}$ hunger and disease [finally] finished them off. Let us go back | to the earlier point. After Abraham Juhari took over the house, he sent [a message] to Egypt, "Come, you will find [here] a place where there are foolish people." A priest called abuna ${ }^{55}$ Girgis came together with his wife. He entered Dayr al-Sultan and | stayed [there]. He cut out [a part] from the place [of Ethiopians] and sold [it] to the Russians for 700 [coins of] gold. It [was] abuna Girgis who sold this place. He soon died. His wife is [still] there. After abuna Girgis came abuna Basiliyus. He, in turn, | expelled completely all the [Ethiopian] monks from their monastery. All the monks lost strength and because they were unsuccessful they departed weeping. Although they complained to the judge, he did not listen to them. [These are] monks [and nuns] who were there at that time |: the mother of rās Baraku, wayzaro ${ }^{56}$ Hirut; Sister Walatta Amānu'ēl; Sister Walatta Takla Haymānot; [Sister] Walatta Māryām from Dāmot; ${ }^{57}$ dabtară ${ }^{58}$ Frē with his wife; Walda Māryām from Hamāsēn ${ }^{59}$ | with his wife; ayā $\bar{c}^{60}$ Kidānu with his wife. King Tewodros said, "wayzaro Sāhlitu is my mother". Also abuna Salāmā ${ }^{61}$ said, "She is [my] child". They said, "Let her stay [in] Dayr al-Sultan, in her place, in the Ethiopian monastery" and they sent her [there and] she came. She entered the house of $\mid$ the community and stayed. It was called the house of the community long ago, in the time of Queen Mentewwāb. ${ }^{62}$

59 Hamāsēn is a region in the northern part of the Eritrean highlands with Asmara as the main urban centre.

6o The Amharic term ayā is a respectful form of address to a man.

61 Amh. abuna Salāmā 'our Father Salāmā'. Salāmā was the Coptic metropolitan of Ethiopia from 1841 to 1867 .

62 Queen Mentewwāb (also known as Berhan Mogasā), mother of Ethiopian Kings of Kings Iyāsu II (1730-1755) and Iyo'as (1755-1769), served as regent during the reigns of her two sons, and held real power in the kingdom until 1769 . 


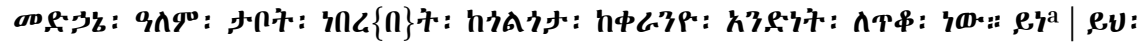

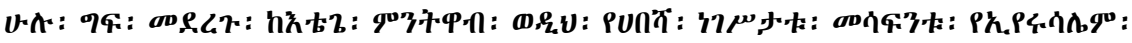

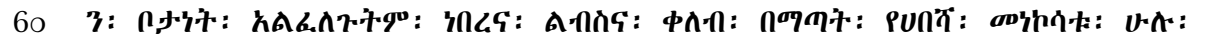

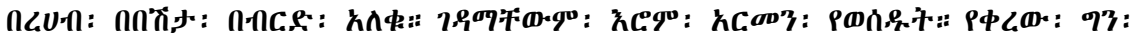

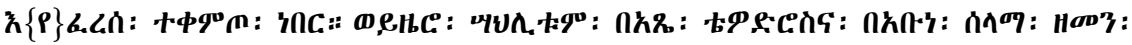

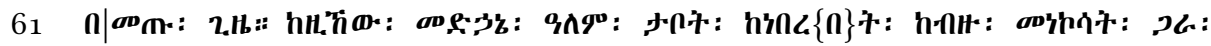

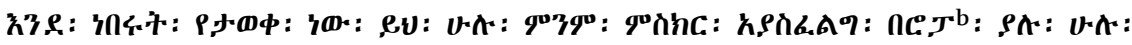

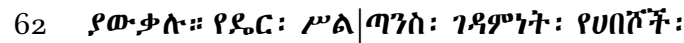

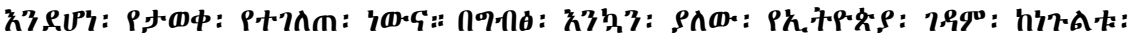

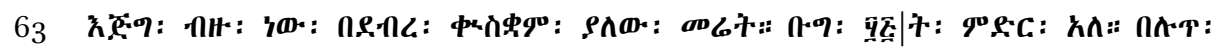

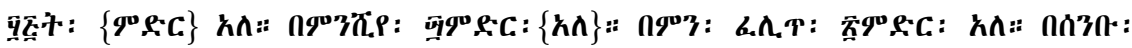

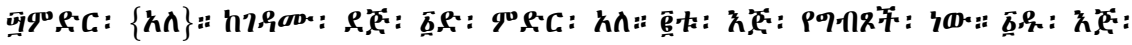

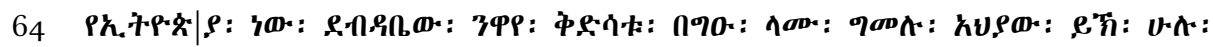

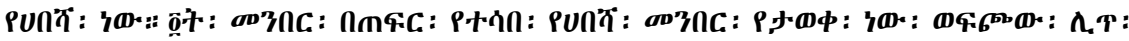

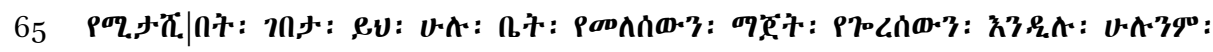

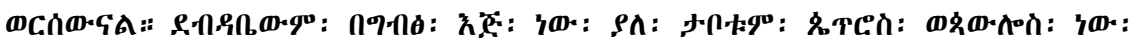

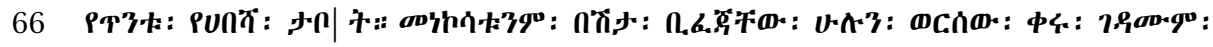

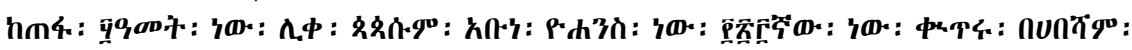

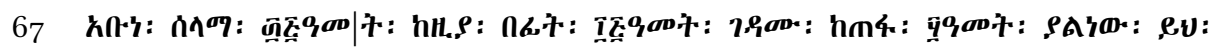
40*:!

a lapsus calami. $\quad$ b Sic for $\mathbf{n} \boldsymbol{\kappa} \boldsymbol{\omega} \cdot \boldsymbol{c}, \boldsymbol{T}$.

63 Amh. tabot. It is a tablet (in wood or stone) placed in an altar chest, which is considered the most sacred object of the Ethiopian orthodox Christianity. The tabot, consecrated and dedicated to God or a saint, sanctifies the church which is usually named after it.

64 Meaning that kings of kings of Ethiopia did not claim their ownership rights over places in Jerusalem.

65 i.e. between 1855 and 1867 .

66 Amh. gult. This term refers to a typical Ethiopian ownership right over land.

67 Amh. dabra qwesqwäm. It is an Ethiopian name for the Dayr al-Muharraq monastery. It is located in Upper Egypt, in Asyut governorate, on the traditional route of Ethiopian

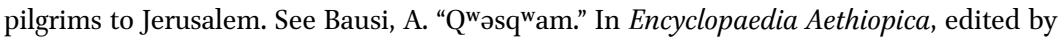
S. Uhlig. Vol. 4, 318. Wiesbaden: Harrassowitz Verlag, 2010.

68 Here starts a passage (pp. 62 to 66) drawn from the Amharic text of 1893. See Appendix no 1.

69 Amh. menshiya. Manshiyya Naser is a now a part of Cairo, traditionally inhabited by Copts.

70 This sentence is totally unclear. What is meant by "outside the monastery"? Is it a reference to Dayr al-Muharraq? The author misinterpreted the anonymous text of 1893 . The 
The altar ${ }^{63}$ of the Holy Saviour [Chapel] was beside [the chapels of] Golgotha [and] Calvary. | For all this violence done from [the time of] Queen Mentewwāb up to now was because the kings and princes of the Ethiopians did not want any place in Jerusalem. ${ }^{64}$ And due to the lack of clothes and food, all the Ethiopian monks | died of hunger, disease and cold. Rome and the Armenians took their [the Ethiopians'] monastery. But the rest [of their possessions] remained there falling into ruin. When wayzaro Sāhlitu came at the time of King Tewodros and abuna Salāmā, ${ }^{65} \mid$ it is well-known that she was there together with many monks [at the place] where the altar of the Holy Saviour was. All this does not need any testimony. Everybody in Europe knows [about it]. For it is known and clear that | Dayr al-Sultan belongs to the Ethiopians.

Even in Egypt there are very numerous Ethiopian monasteries with their fief: 66 The land which is at Dayr al-Muharraq; ${ }^{67}$ [in] ${ }^{68}$ Bug there are 55 | plots; in Lut' there are 55 plots; in Manshiyya ${ }^{69}$ there are 40 plots; in Men Falit' there are 20 plots; in Sanbu there are 40 plots. Outside the monastery there is 1 plot -2 portions belong to the Egyptians, 1 portion belongs to Ethiopia. ${ }^{70} \mid$ Documents, sacred vessels, sheep, cows, camels, donkeys, all this belongs to the Ethiopians; [also] four chairs which are made out of leather strips are known as Ethiopian chairs; [also] a mill [and] a large bowl for kneading dough |, any kind of furnishing in the house, everything which is in the kitchen, all this they [the Egyptians?] inherited from us. The documents are in the hands of the Egyptians [and so is] the altar, [dedicated to Saint] Peter and [Saint] Paul, [which is] an ancient Ethiopian altar. | When disease finished off the [Ethiopian] monks, [the Egyptians] inherited everything and remained [there]. It is 50 years since the monastery was lost. The patriarch was abuna John the 123th. ${ }^{71}$ In Ethiopia it was 35 years since [the tenure of] abuna Salāmā $\mid$ and 15 years before [today]. ${ }^{72}$ Hence is the 5 o years, as we said, since the monastery was lost. ${ }^{73}$

latter says that for all plots in Egypt mentioned here, two-thirds belong to the Egyptians and one-third to the Ethiopians.

71 Amh. abuna yohannes 123nyāw. This reference to a Coptic patriarch John seems to be invented. There were not 123 patriarchs during the entire history of the Coptic Church. Perhaps it is a reference to Yu'annis (John) XVIII who was in tenure between 1769 and 1796. See Chapter 3, p. 68 and Chapter 5, p. 139.

72 This sentence was inserted by the author of the text in order to complete and clarify the previous sentence from the 1893 text. 35 years since Salāmā means $1875 / 1876$. By adding 15 years, we obtain $1890 / 1891$, the date which, according to the author, was the year when the Amharic text copied by him was composed. See Chapter 3, pp. 68-69.

Here ends the passage copied from the Amharic text of 1893 . 


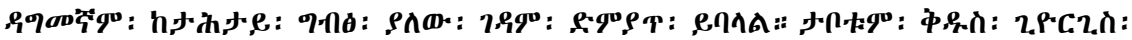

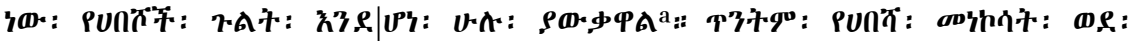

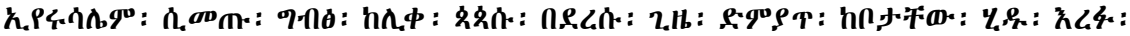

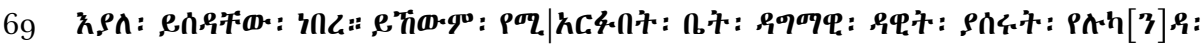

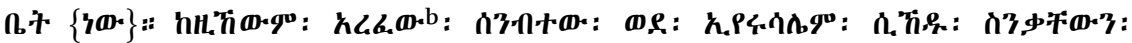

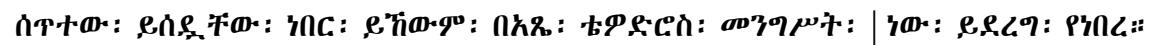

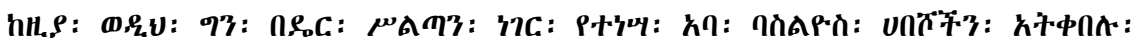

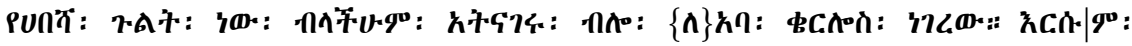

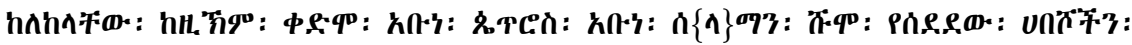

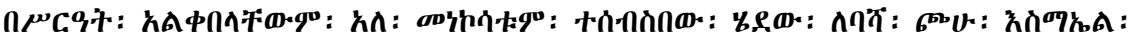

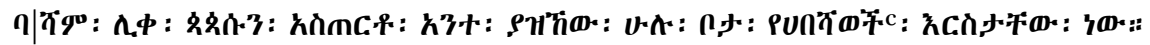

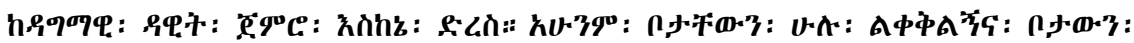

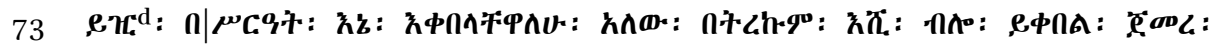

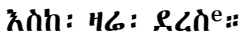

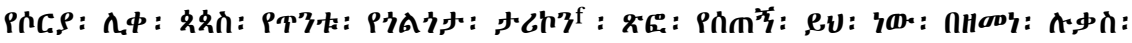

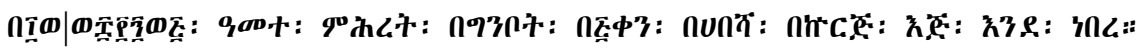

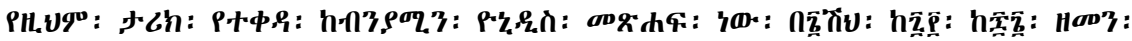

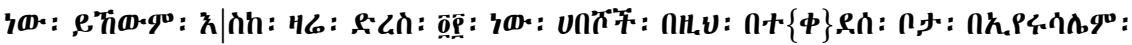

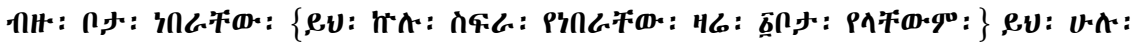

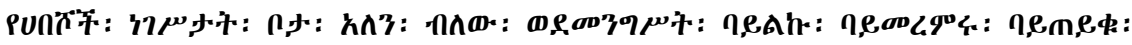

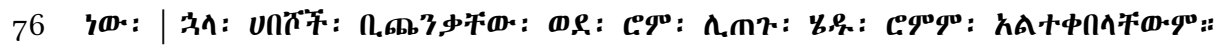

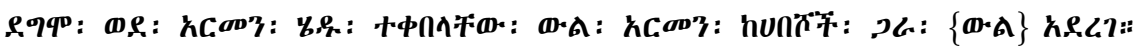

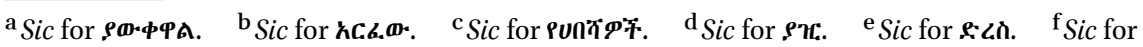
+Gh?'
}

$74 \quad$ Here starts a passage composed by the author himself which continues up to page 73 .

75 Amh. demyāt'.

76 Ethiopian King of Kings Dāwit II reigned from 1380 to 1413.

$77 \quad$ Amh. abbā qērlos. Coptic patriarch Kirillus (Cyril) v in tenure between 1874 and 1927.

78 Amh. abuna pēt'ros. Coptic patriarch Butrus (Peter) VII in tenure between 1809 and 1852 .

79 Amh. esmäè è bāshā. Isma'il Pasha was the khedive of Egypt and Sudan from 1863 to 1879.

8o May 13, 1903AD. The patriarch mentioned here is probably Iwanis Ili Halluni in tenure at that time. Ferrand, La diaspora syriaque-orthodoxe, 191. The passage, beginning from this sentence up to page 91, was copied from an unknown text (divided into four chapters), which the patriarch gave to the author.

81 The year 6766 of the Alexandria World Era corresponds to 1274AD. Thus 400 years after means 1674AD. 
Furthermore, ${ }^{74}$ the monastery which is located in Lower Egypt is called Damietta. ${ }^{75}$ Its altar is [dedicated to] Saint George. Everyone knows that it is $\mid$ a fief of the Ethiopians. Long ago, when Ethiopian monks were on their way to Jerusalem, when they reached the [Coptic] patriarch in Egypt, he used to send them to Damietta saying: "Go to your place [and] have a rest." The house | in which [the Ethiopians] would rest, [and] which Dāwit II ${ }^{76}$ had founded, was an inn. They would stay there for a few days [and] upon departing for Jerusalem [the people there] used to give them provisions and send them on. This was done during the reign of King Tewodros. | But after that, because of the issue of the Dayr al-Sultan monastery, Father Basiliyus told Father Kirillus, ${ }^{77}$ "Don't welcome the Ethiopians. Don't say [that] it is an Ethiopian fief'". So [Father Kirillus] | refused [to accommodate] them. Before that abuna Butrus, ${ }^{78}$ who appointed and sent [to Ethiopia] abuna Salāmā, said, "I will not welcome the Ethiopians". The [Ethiopian] monks gathered, went to the pasha and complained to him. Ismacil | Pasha ${ }^{79}$ called the patriarch: "All the places that you have taken are the Ethiopians' property, starting from [the reign of] Dāwit II up to me. Now then, leave all their places to me and I will take them over. [And] I will welcome | them officially," he said. The patriarch said "I agree" and [the pasha] started welcoming [the Ethiopians], up to now.

This is the ancient history of Golgotha which the Syriac patriarch wrote and gave to me in the era of [Saint] Luke in 1895 year of mercy on the $5^{\text {th day of }}$ Genbot. ${ }^{80}$ [Golgotha] was in the hands of the Ethiopians [and] Georgians. This history was copied from a book [written] by Benjamin Ioannidès. It was in the year 6766 . | [From then] up to now it has been 400 [years]. ${ }^{81}$ In this holy place, in Jerusalem, the Ethiopians had numerous places. $\{[\mathrm{Of}]$ all those places, they have not even one today\}. All this is because the kings of the Ethiopians did not say, "We have a place [in Jerusalem]" 82 and they did not send [any messages] to the authorities [of Jerusalem], they did not examine [the situation], they did not show interest [in it]. ${ }^{83} \mid$ Later, because the Ethiopians were in distress they went to Rome ${ }^{84}$ in order to come closer [to the Greek Orthodox authorities]. But Rome did not accept them. Then, they went to the Armenians [and] they accepted them. The Armenians made an agreement with the Ethiopians. The

\footnotetext{
$82 \quad$ Meaning that kings of kings of Ethiopia did not defend or protect their ownership rights over places in Jerusalem.

83 Lit. 'they did not ask [about it]'.

84 'Rome' means Constantinople.
} 


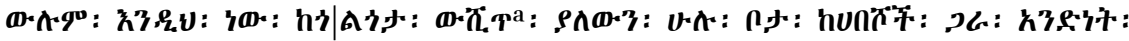

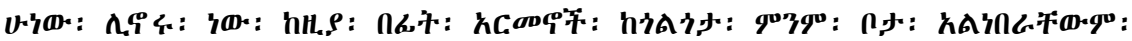

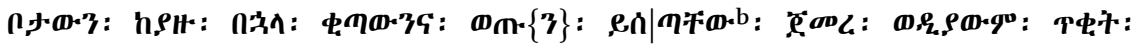

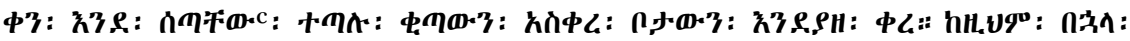

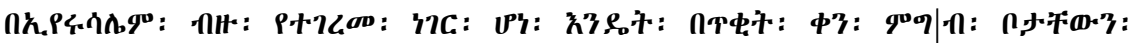

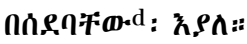

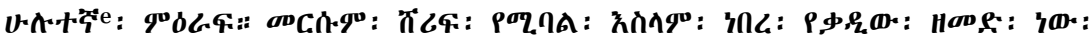

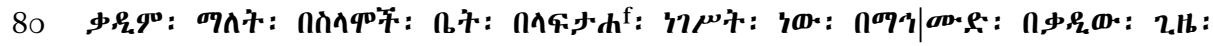

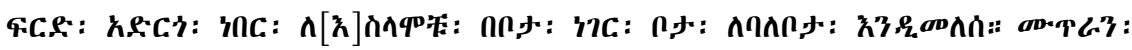

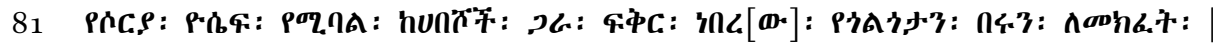

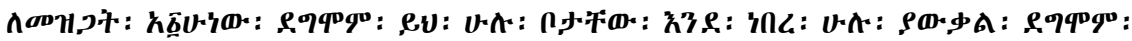

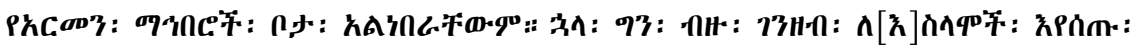
82 ก,

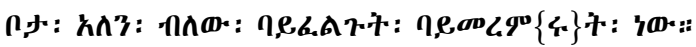

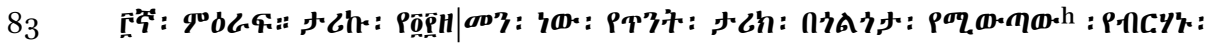

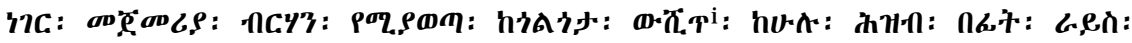

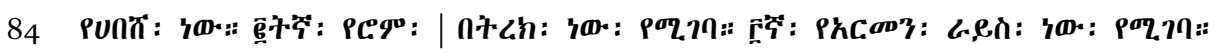

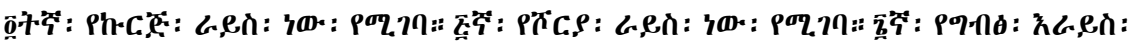

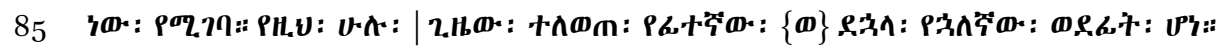

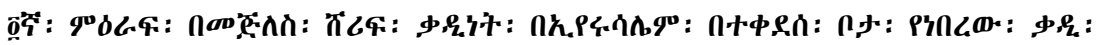

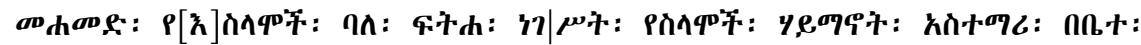

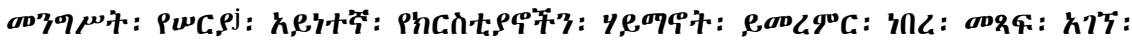

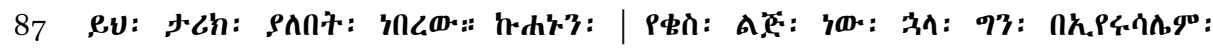

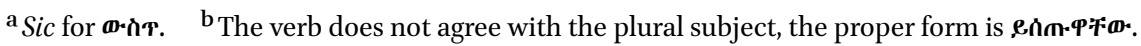
${ }^{\mathbf{c}}$ The dummy subject of this and the next sentence is in the singular form in contrast to the plu-

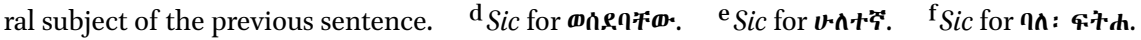

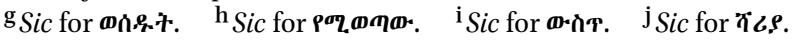

85 'Golgotha' here means the entire Holy Sepulchre complex.

86 This is the second chapter of the document given to the author by the Syriac patriarch. The first chapter is the previous paragraph.

87 Amh. fetha nagast. The Law of the Kings is a Christian book of law, written in Gecez (translated from Arabic) and applied in Ethiopia from the 16th century onwards. It deals with religious and civil matters.

88 Amh. māhmud. Perhaps it refers to the Ottoman Sultan Mahmud Khan I (1730-1754).

89 This paragraph concerns the ceremony of the Holy Fire (in Ge'ez redata berhan 'Descent of the Light') which takes place annually at the Church of the Holy Sepulchre on the Orthodox Good Friday.
} 
agreement went like this: | [the Armenians] will live together with the Ethiopians in all places which are inside Golgotha. ${ }^{85}$ Before that, the Armenians did not have any place at Golgotha. After they took the places, they [the Armenians] started to give them [the Ethiopians] some bread and stew. |At once, after a few days of giving them [food], they began to argue with each other. They [the Armenians] stopped giving bread but the places remained occupied [by them]. After that, it became something very surprising [in] Jerusalem. [People] were saying: "How come [the Armenians] took the places [of the Ethiopians] | [in exchange] for several days of food?"

Chapter Two. ${ }^{86}$ There was a Muslim called Marsum Sharif. He was a relative of the qadi. In the Muslim community qadi means a person versed in The Law of the Kings. ${ }^{87}$ In the time of Mahmud, ${ }^{88}$ | the qadi dispensed justice for the Muslims [stating that, in case of a dispute] over a place, [the place] would be returned to the owner. The metropolitan bishop of Syria called Yosēf was a friend of the Ethiopians. He used to open and | close the door of Golgotha in agreement [with the Ethiopians]. Furthermore, he also knew that all this was their [the Ethiopians'] place, and also [that] the Armenian communities did not have a place. But later [the Armenians] gave much money to the Muslims [and] they took | all the places of the Ethiopians and the Georgians. All these places were lost because the kings [of Ethiopia] did not want [them and] did not search for them, saying "We have a place".

Chapter Three. The history spans 400 | years. The fire which appears at Golgotha $^{89}$ [is] an ancient story. It is the Ethiopian superior [who] first [receives] the fire which appears inside Golgotha, before all [other] people; the second to enter [Golgotha] is the patriarch $\mid$ of Rome; the third to enter is the Armenian superior; the fourth to enter is the Georgian superior; the fifth to enter is the Syriac superior; the sixth to enter is the Egyptian superior. All this $\mid$ has changed over time. The first has become the last $\{$ and $\}$ the last has become the first.

Chapter Four. Qadi Muhammad who was in the noble council of justice ${ }^{90}$ in Jerusalem in the holy place, [and who was] a teacher of Muslim religion, versed in the Law of the Kings of the Muslims, | [and] the Sharia main [expert] in the governmental palace, studied the religion of the Christians. He found a book which contains this story. Kuhanun | was the child of a priest. He was appointed metropolitan bishop of the Syriac community in a monastery in Jerusalem. And 


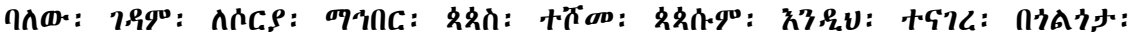

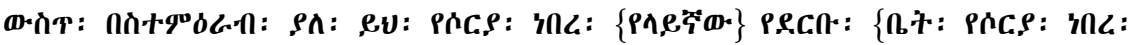

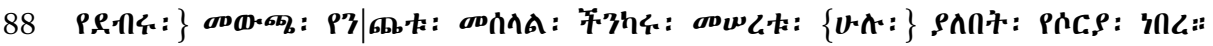

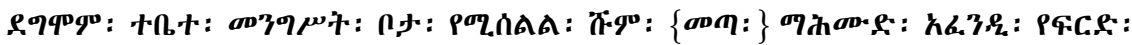

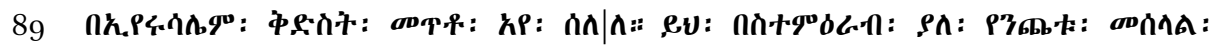

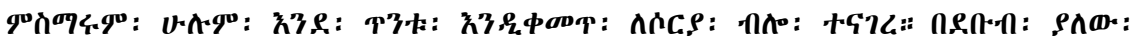

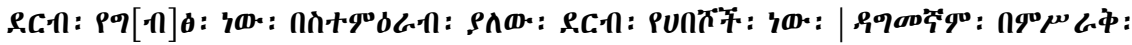

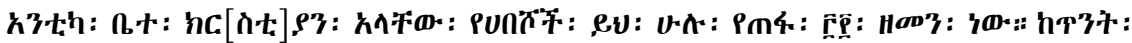

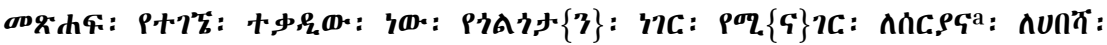

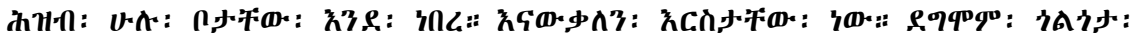

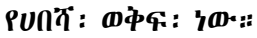

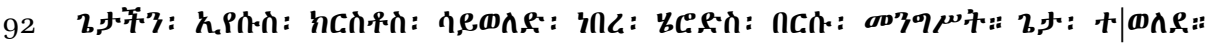

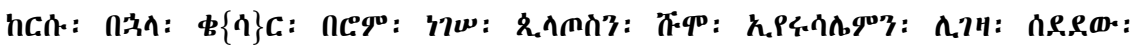

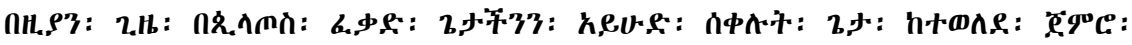

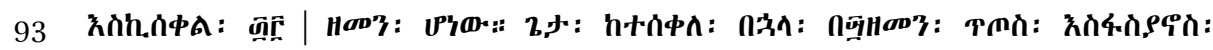

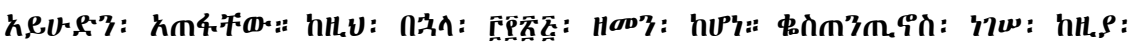

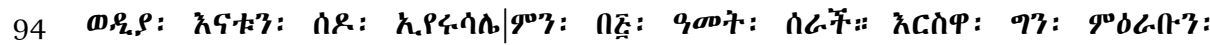

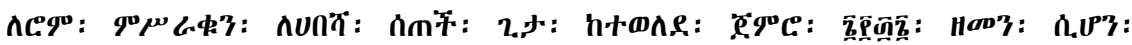

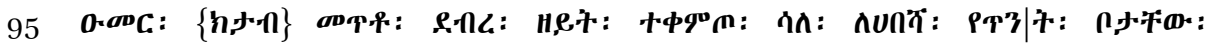

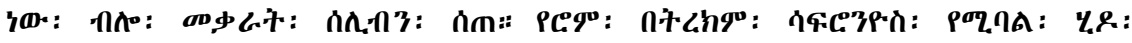

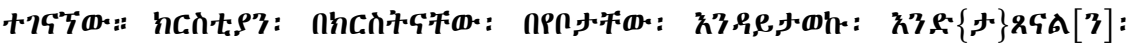

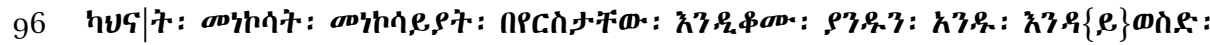

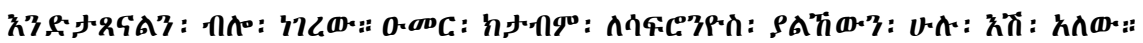

\footnotetext{
a Sic for ince.

91 Lit. 'the exit'.

92 The meaning of the word antikā is unknown to us.

93 This means the entire Holy Sepulchre complex.

94 In Muslim law, a waqf is a property given to religious establishments. By using this term, the author wants to give the equivalent in Muslim law of the Ethiopian term rest 'property' which he employs in the previous sentence.

95 Here starts a passage (pp. 91-115) which originates from the Amharic text dated 1893, based on the works by the Greek historian Ioannidès. See Ioannidès, Proskynetarion tis Agias Gis. Vol. 1, 146-152, 184-202, 225-227.

96 Amh. qēsār. A generic term for the Roman emperor.

97 Amh. t'et'os esfäsyānos. Roman emperor from 69 to $79 \mathrm{AD}$.

98 Amh. qwast'ant'inos. Roman emperor from 306 to 337 AD.
} 
[this] metropolitan bishop said like this, "Inside Golgotha, [the part] which is to the west belonged to Syria. \{The upper floor of the building belonged to Syria\}. The entrance ${ }^{91}$ \{of the basilica\}, the wooden ladder, | its foot and the whole ground where [the entrance] was, belonged to Syria." Besides, one official \{came\} from the governmental palace, spying on the place. Mahmud Effendi, an [official] of justice in the Holy Jerusalem, came, looked [and] | spied. He said, "Whatever is to the west, the wooden ladder and the foot, let everything continue to belong to Syria as [it was] long ago. The upper floor to the South belongs to Egypt. The upper floor to the west belongs to the Ethiopians. | Additionally, in the eastern antik $\bar{a}^{92}$ [the Ethiopians] have a chapel". All this [that used to belong to] the Ethiopians was lost 300 years ago. [All this] was found in the ancient book of the qadi which talks about the issue of Golgotha. ${ }^{93}$ | We know that it was the place of all people of Syria and of Ethiopia. It is their property. Also, Golgotha is Ethiopian waqf. ${ }^{94}$

Before our Lord Jesus Christ was born there was Herod. ${ }^{95}$ The Lord was born during his reign. | After him caesar ${ }^{96}$ reigned in Rome. He appointed Pilate and sent him to rule Jerusalem. At that time, the Jews crucified our Lord with the permission of Pilate. From [the time when] the Lord was born until he was crucified, 33 | years passed. 40 years after the Lord was crucified Titus Vespasian ${ }^{97}$ massacred the Jews. After that, in the year 325 , Constantine became emperor. ${ }^{98}$ Next, he sent his mother ${ }^{99}$ and she rebuilt Jerusalem | in five years. She gave the west [of the Golgotha church] to Rome and the east to Ethiopia. In the year 636, after the birth of our Lord, 'Umar \{ibn al-Khattab $\}^{100}$ came; and when he was staying on the Mount of Olives he said, | "This is an ancient place of the Ethiopians" and he gave [them] the place of the Cross. ${ }^{101}$ The patriarch of Rome, called Sophronius, ${ }^{102}$ went [there] and met him ['Umar]. He told him, "Assure us that the Christians will not be disturbed because of their Christianity in their respective places, that priests, | monks and nuns will stay in their respective properties, that one will not take [the property] of another. Assure us". To everything that Sophronios said, 'Umar ibn al-Khattab answered, "I agree". He wrote

\footnotetext{
99 Empress Helena (c. 250-c. 330).

100 Amh. umar $\{k e t a \bar{b}\}$. 'Umar ibn al-Khattab was a companion of the prophet Muhammad and the second caliph from 634 to 644 .

101 Amh. maqārāt salib from Arabic. Maqārāt: most probably from mäqarat 'place'? salib 'cross'.

102 Amh. sofronyos. Sophronius was the patriarch of Jerusalem, subordinate to Constantinople from 634 to 638 .
} 


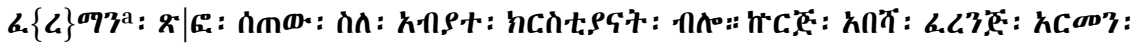

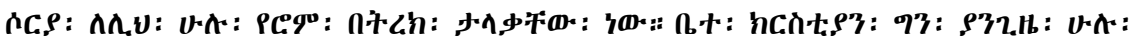

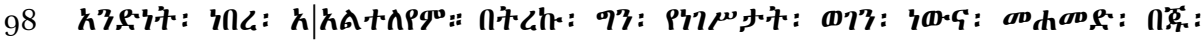

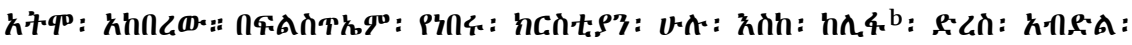

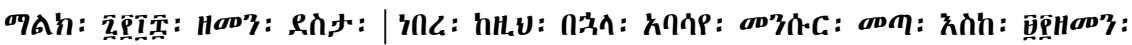

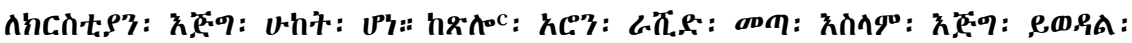

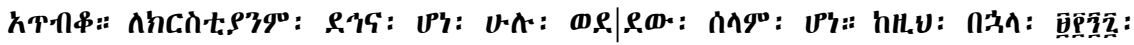

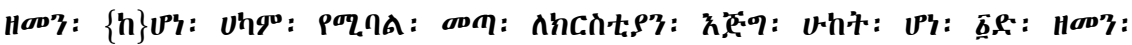

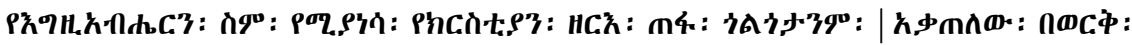

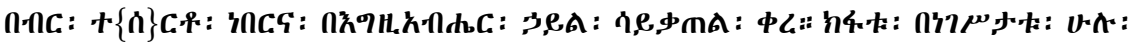

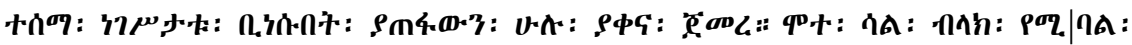
PA' : А ev: v.n: n.

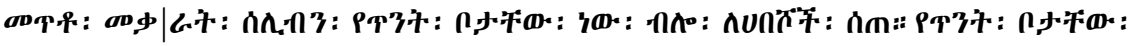

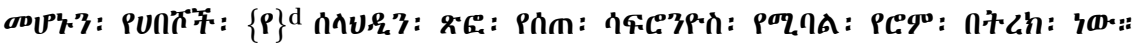

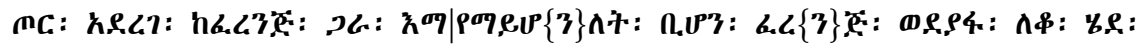

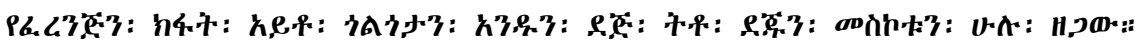

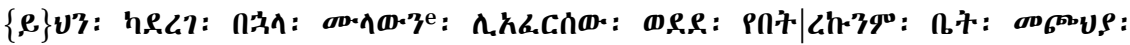

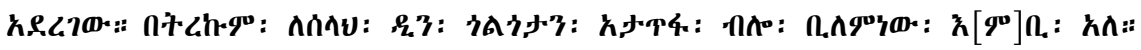

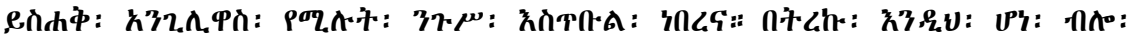

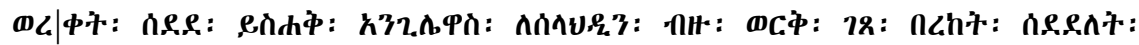

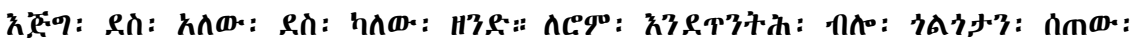

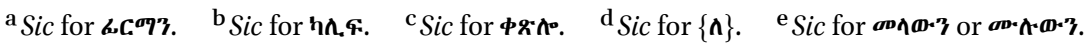

103 This means the patriarch of Constantinople.

104 Lit. 'he printed his hand on him'.

105 Amh. abdel mālek. 'Abd al-Malik was the fifth Umayyad caliph from 685 to 705 . The date 718 given here does not correspond to the date of his reign, but the author follows the information given by Ionannidès. See Ioannidès, Proskynetarion tis Agias Gis. Vol. 1, 146.

106 Amh. abāsāya mansur. Al-Mansur was the second Abbasid caliph from 754 to 775 .

107 The author's mistake. The original text, written by the Greek historian Ioannidès, says "until the gth century".

108 Amh. aron rāshid. Harun al-Rashid was the fifth Abbasid Caliph from 786 to 809 .

109 Amh. hakām. Al-Hakim was the sixth Fatimid Caliph from 996 to 1021.

110 Lit. 'heard'.

111 Despite the fact that al-Mustansir bi-llah the eighth Fatimid caliph (1036-1094) was indeed al-Hakim's grandson, the author most probably meant 'Ali al-Zahir, the seventh Fatimid caliph (1021-1036), who permitted the rebuilding of the Holy Sepulchre.
} 
an edict | concerning the Christian settlements and gave it to him. For all of them: the Georgians, the Ethiopians, the Faranj, the Armenians [and] the Syrians, the patriarch of Rome ${ }^{103}$ was the superior. At that time the whole Church was unified. | It was not divided. The patriarch belonged to the monarchy and Muhammad recognized him ${ }^{104}$ and gave him respect. [For] all of the Christians who were in Palestine until Caliph 'Abd al-Malik, the year $718,{ }^{105}$ there $\mid$ was joy. After that the Abbasid al-Mansur ${ }^{106}$ came. Until the year $900^{107}$ there was great violence against the Christians. Next, Harun al-Rashid ${ }^{108}$ came. He loved Islam immensely. He was also good to the Christians. Everyone | loved him. Peace prevailed. After that, in the year 997 [a caliph] called al-Hakim ${ }^{109}$ came. There was great violence against the Christians. [In] one year, the Christian race which was calling on the name of God vanished. [Al-Hakim] set | Golgotha on fire. [But] because it was made of gold and silver, [and] by the power of God, [Golgotha] did not burn. His wickedness was recognized ${ }^{110}$ by all kings. When the kings arose against him, he began to restore everything that he had destroyed. When he died, his grandson called Sāl Belāk ${ }^{111} \mid$ completed it. After that, in the year 110o, the Faranj came. ${ }^{112}$ They ruled for 88 years. While all this was happening, the Ethiopians did not release their hold. In the year $1087,{ }^{113}$ [a ruler] called Salah al-Din ${ }^{114}$ came and saying, "The place | of the Cross ${ }^{115}$ is their ancient place", he gave it to the Ethiopians. It was the patriarch of Rome called Sophronius who [originally] wrote and [indirectly] let Salah al-Din know that it was an ancient place of the Ethiopians. ${ }^{116}$ [Salah al-Din] made war against the Faranj. | When it was unsuccessful for them, the Faranj surrendered and went to Jaffa. When he [Salah al-Din] saw the wickedness of the Faranj he left one entrance of Golgotha [open and] closed off all the [other] entrances and windows. After he did that, he wanted to destroy the entire [church]. He made the house of the patriarch | into a mosque. ${ }^{117}$ Although the patriarch begged Salah al-Din not to destroy Golgotha, [Salah al-Din] refused. There was a king in Istanbul [called] Isaak Angelos ${ }^{118}$ and so the patriarch sent [him] a letter saying what had happened |. Isaak Angelos sent to Salah al-Din much gold [and] gifts. He [Salah al-Din] was very pleased and in his delight he gave Golgotha

\footnotetext{
112 This means the Crusaders.

113 The author's mistake. Ioannidès' text gives the year 1187 .

114 Amh. salāhdin. Salah al-Din (Saladin) was the first Ayyubide Sultan of Egypt from 1169 to 1193 .

115 Amh. maqūrrāt salib. See footnote 101.

116 In other words, Saladin upheld what had earlier been decided by Sophronius.

117 Lit. 'a place of [Muslim] call to [prayer], a minaret'.

118 Amh. yeshaq angilēwās. Isaak II Angelos was Byzantine emperor from 1185 to 1195. Here the mention of Constantinople as 'Istanbul' is an anachronism.
} 


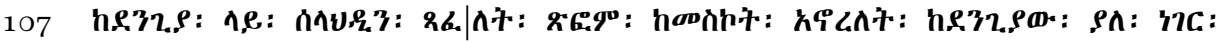

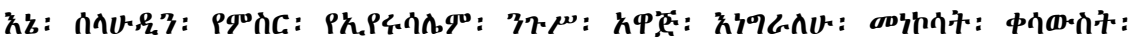

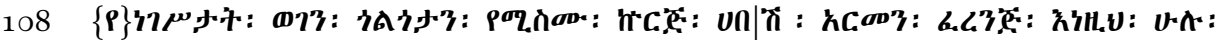

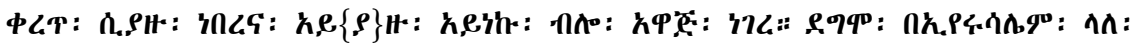

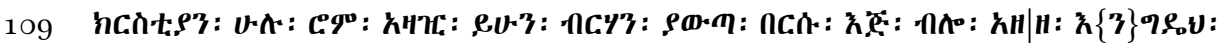

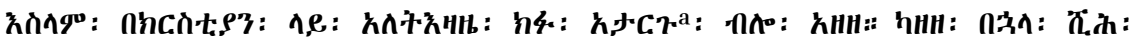

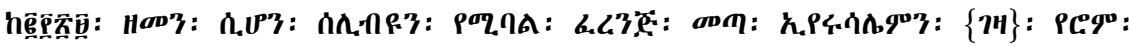

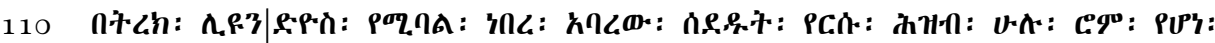

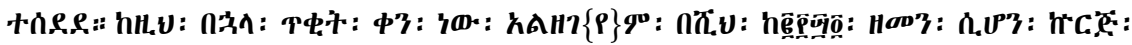

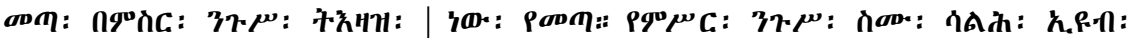

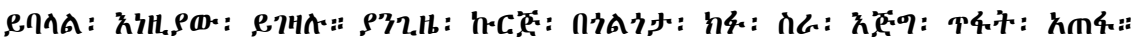

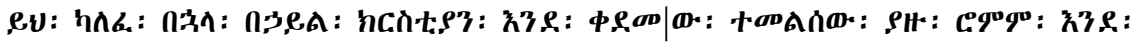

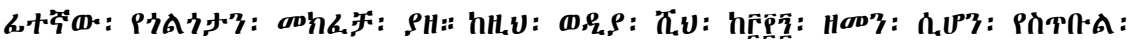
37.

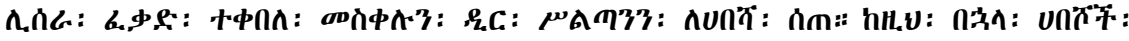

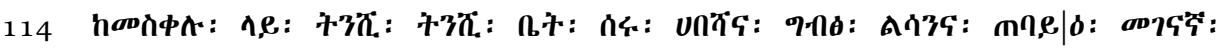

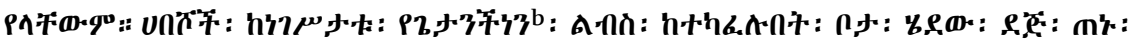

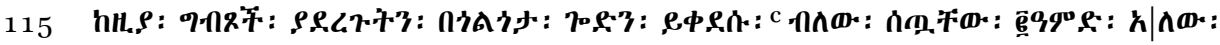

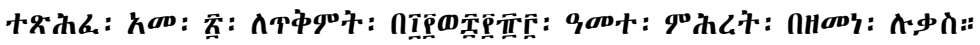

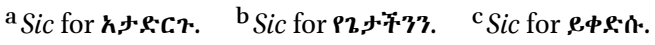

119 i.e. to the Orthodox Greeks.

120 Amh. habash. The author used here the Arabic or Ottoman Turkish form ('habash' or 'habaş') of habashā.

121 We could not identify this name. The author probably means Frederick II, the Holy Roman emperor from 1220 to 125 .

122 i.e. the Orthodox Greeks.

123 Lit. 'it was not later than a few days'.

124 Amh. kurj. The author used the same word before in reference to the Georgians. But here he definitely refers to the Khwarezmian Tatars who devastated Jerusalem between 1244 and 1247 .

125 sālh iyub. Al-Salih Ayyub was the Ayyubid Sultan of Egypt from 1240 to 1249.

126 This is an obscure, incomplete sentence.
} 
to Rome, ${ }^{119}$ saying "As it [was] yours before". Salah al-Din wrote for him [a text] on a stone $\mid$ and placed it for him by a window. The thing [written] on the stone was: "I, Salah al-Din, king of Egypt and Jerusalem, proclaim [this] edict". As the tax was to be levied on all of them: monks, priests, the nobility, the Georgians, the Ethiopians, ${ }^{120}$ | the Armenians, the Faranj who visit Golgotha, [Salah alDin] proclaimed an edict saying: "Let [the tax] not be levied on them, and let them not be disturbed." Besides, he ordered, "Let Rome be the chief of all Christians who are in Jerusalem, let the Holy Fire be lit in [Rome's] hand". | Also he ordered the Muslims, "Do not do any evil to the Christians without my command". After he ordered [that], in the year 1229 came a Faranj called Salibyon. ${ }^{121}$ $\mathrm{He}$ \{ruled\} Jerusalem. The patriarch of Rome was called Liyondyos. | He [Salibyon] expelled him and banished him. All of his people who were Romans ${ }^{122}$ were banished. Next, after some time, ${ }^{123}$ in the year 1244 came the Tatars. ${ }^{124}$ They came on the orders of the king of Egypt. | The name of the king of Egypt was al-Salih Ayyub. ${ }^{125}$ Those were ruling. ${ }^{126}$ At that time, the Tatars committed a misdeed, a great violation at Golgotha. After this occurred, the Christians returned in force as before | and took [Golgotha]. Rome, as previously, took the key of Golgotha. After that, in the year 1390 the king of Istanbul, called John Kantakouzenos, ${ }^{127}$ received permission from the king of Egypt to [re]build Jerusalem [and] | what the Tatars had destroyed. He gave the [sanctuary of the] Cross and Dayr al-Sultan to the Ethiopians. After that, the Ethiopians built several small houses above the [sanctuary of the] Cross. The Ethiopians and the Egyptians share neither language nor character. | The Ethiopians went to the kings ${ }^{128}$ to the place where the clothes of our Lord were divided and appealed [to them]. After that, saying, "Let them celebrate the liturgy beside Golgotha", they gave them two pillars, ${ }^{129}$ which the Egyptian made their own. ${ }^{130}$ | It was written on the 2oth of t'eqemt in 1883 year of mercy, in the era of Luke. ${ }^{131}$

127 Amh. yohannes kotkwazēno. John vi Kantakouzenos was a Byzantine emperor from 1376 to 1379. The date 139 o given here does not correspond to the date of his reign, but the author follows the information given by Ioannidès. See Ioannidès, Proskynetarion tis Agias Gis, 226.

128 Ioannidès says 'to the sultan'. See Ioannidès, Proskynetarion tis Agias Gis, 226.

129 i.e. the space between two of the tall stone columns which demarcate subspaces within the basilica of the Holy Sepulchre. The author changes the meaning of Ioannidès' text. In the latter, Copts obtained the right to perform liturgy there, not Ethiopians. So in the original sentence, 'them' refers to the Copts, not to the Ethiopians. See Ioannidès, Proskynetarion tis Agias Gis, 226.

130 Here ends the passage taken from the Amharic text of 1893 .

131 October 30, 1890AD. 


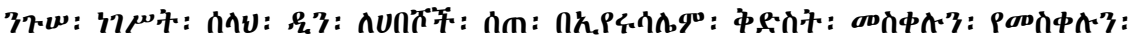

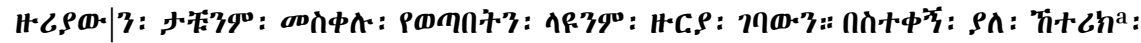

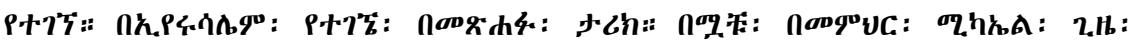

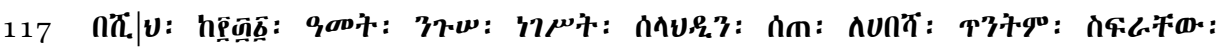

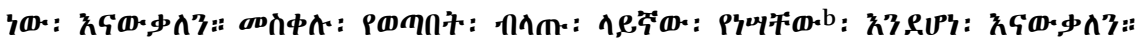
118 P7.,

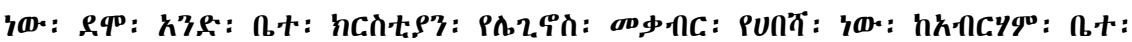

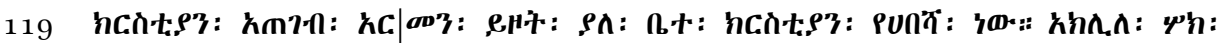

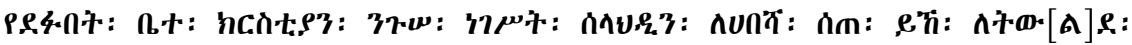

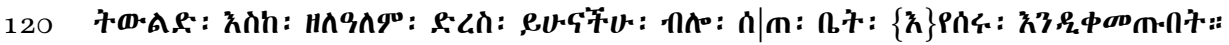

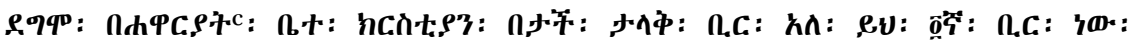

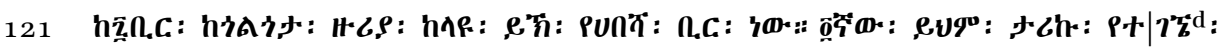

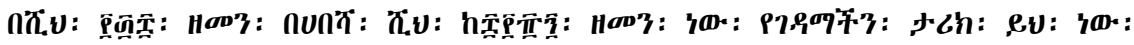

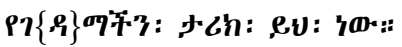

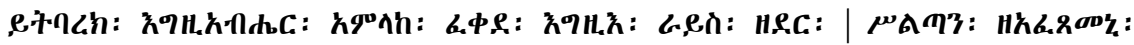

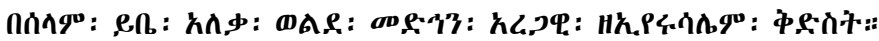

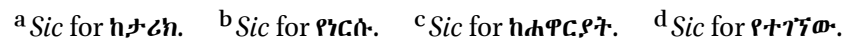

132 Lit. 'was taken out'.

133 In other words, the monastery of Dayr al-Sultan, the whole terrace, the two chapels of Saint Michael and of the Four Living Creatures, and also the Armenian Chapel of Saint Helena and the Latin Chapel of the Finding of the Cross.

134 We have not managed to find any information either about the abbot Mikāèl or about this book. 
King of Kings Salah al-Din gave to the Ethiopians in the Holy Jerusalem: the [sanctuary of the] Cross, the surrounding area of the [sanctuary of the] Cross, | [the sites] below where the Cross was found, ${ }^{132}$ [the sites] above and the surroundings which are to the right. ${ }^{133}$ [This] was found in the history. This was found in the history, in Jerusalem, according to the history in the book, in the time of the late abbot Mikäēel. ${ }^{134}$ In the year 1131 | King of Kings Salah al-Din gave [it] to the Ethiopians. ${ }^{135}$ We know that it was their place from ancient times. We know that the covering of the roof above the place where the Cross was found is theirs. [The place] around the monastery, | the Chapel of the Apostles [and] the old big door belong to the Ethiopians. ${ }^{136}$ Also, one chapel [with] the grave of Longinus belongs to the Ethiopians. ${ }^{137}$ The chapel which is next to the Chapel of Abraham and which was taken by the Armenians | belongs to the Ethiopians. ${ }^{138}$ King of Kings Salah al-Din gave to Ethiopia the church in which was placed the crown of thorns. ${ }^{139}$ He gave [it] saying, "May this belong to you for all generations forever". | So that [the Ethiopians] will build a house in which they will stay. Also, below the chapel of the Apostles there is a big well. ${ }^{140}$ This is the fourth well, out of seven cisterns [which are] around Golgotha. This fourth [well] is an Ethiopian well. This history was found | in the year 1138, according to the Ethiopians in the year $188 \mathrm{o}-1890 .{ }^{141}$ This is the history of our monastery. This is the history of our monastery.

May God be blessed, the Lord of Faqada Egzie, superior of Dayr | al-Sultan, ${ }^{142}$ who made me finish in peace, says alaqā Walda Madhen Aragāwi of the Holy Jerusalem.

\footnotetext{
135 In 1131 Salah al-Din had not yet been born.

${ }_{13} 6$ This refers to the present-day Coptic chapel dedicated to Saint Helena with the door leading to the terrace of Dayr al-Sultan located just in front of it.

137 The chapel of Longinus, located inside the Holy Sepulchre basilica, under Greek supervision.

138 Probably the Chapel of the Sharing of the Raiment under the supervision of the Armenians, located in the ambulatory of the Holy Sepulchre basilica, near the entrance of the Armenian Saint Helena Chapel.

139 Probably the author is referring here to the Chapel of Insults under Latin supervision, located next to the Chapel of Longinus.

140 Under the present-day Coptic Chapel of Saint Helena.

141 What does the author mean? We do not know in which calendar the date 1138 was calculated. Is it the date (in the Gregorian calendar) of Salah al-Din's decree whereas the date ' $188 \mathrm{o}-189 \mathrm{o}$ ' is the period of time when the Ethiopians found the book mentioned earlier? We cannot be sure.

142 Faqada Egzi'e was the abbot of Dayr al-Sultan between 1902 and 1906.
} 